\title{
電気探査より見た高知県下の破砕帯型 地すべり地について
}

\section{竹内 篤 雄* \\ On the Fractured Zone Type Landslide in Kōchi Prefecture by the Electrical Resistivity Survey}

\section{by Atsuo Takeuchi}

The usefullness of the electrical resistivity survey in the Fractured zone type landslide was examinated at Chōja landslide area and Wada landslide area in Kōchi prefecture which had many same type landslide. As the result, it was clear that the usefullness of the electrical resistivity survey existed in the Fractured zone type landslide as well as in Tertiary type landslide, and that many informations on the investigated landslide area were pointed out by the electrical resistivity survey.

Thereupon the writer carried out the electrical resistivity survey in order to investigate the usefullness thoroughly, at many other Fractured zone type landslide areas in Kōchi prefecture. And the writer tried to examinate the Fractured zone type landslide from the information on the each landslide which was obtained by the electrical resistivity survey.

As the result of this investigation and study, the next informations were gotten:

1. From the assumed diagrams of the underground profile

a. Outline of the underground structure of the landslide area.

b. Fairly exactive informations on the form and depth of slide-surface and bedrock layer.

c. The landslide area could be divided some meaning blocks on account of the landslide area's topographical map which plotted the uncontinuous places of resistivity value seeing the assumed diagrams of underground profile.

d. Even if the bedrock existed so deeply and could not assumed the existed depth of bedrock by the electrical resistivity survey, the shallow slide layer which damaged to the field and houses was detected sufficiently by the electrical resistivity survey.

2. From the analysis of distribution diagrams of low apparent resistivity

a . It was assumed that the distribution area of low apparent resistivity indicated next area: 1 . existing area of aboundant underground water, 2. violent area of landslide displacement, 3. accelerating area of weather of landslide soil mass, 4. possibility existing area which occured landslide displacement in future.

b. In conformity to combine the uncontinuous places of resistivity values which were obtained by the assumed diagrams of underground profile and distribution diagrams of low apparent resistivity, the landslide area was divided same meaning blocks. And in case of making clear the displacement mechanism of the landslide, each divided blocks in the landslide area were having important means.

\section{1. はじめに}

破砕帯型地すべり地における電気探查の有意性（usefullness）については, 同型地すべり地の数多く分布す る高知県下の長者地すべり地および和田地すべり地の調 査結果を例にあげてすでに検討がなされている1”。その 結果，同型地すべり地においてす第三紀層型地すべり地 之同様に電気探査の有意性が存在し, 調査地すべり地に

* 京都大学防災研究所 助手
ついて数多くの情報を提供してくれることが判明してい る。そこで，笵者は高知県下に分布する他の破砕帯型地 すべり地においても電気探査を実施し，その有意性をさ らに追求するととあに，電気探查により得られた各地す ベり地に関する情報から破砕带型地すべり地というもの をながめてみた。

なお，この研究は現在継続中であるが，乙れまでにい くつかの興味ある事柄が見い出されたので，乙こに簡単 にまとめてみるしだいである。 


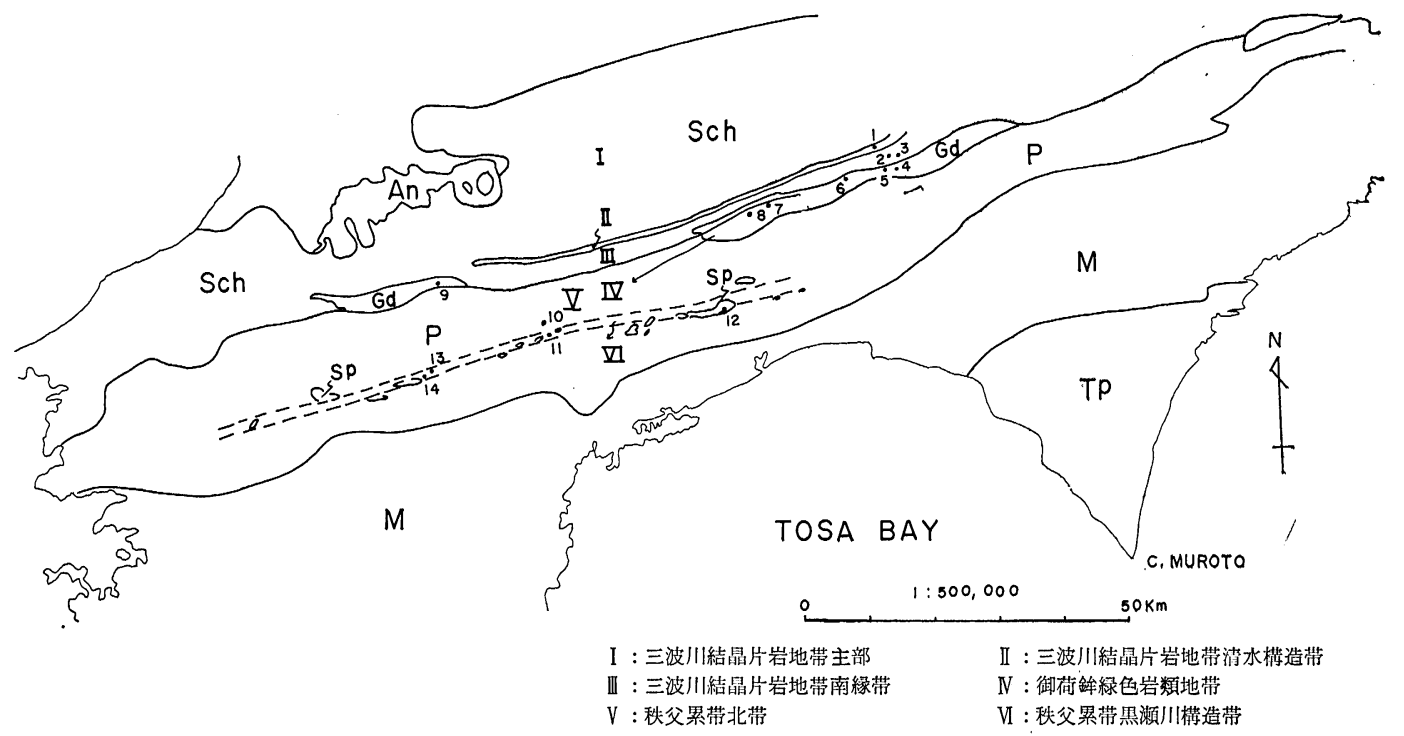

図-1 調查地すべり地位㯰図

\section{2. 高知県下における地すべり地について}

高知県下で地すべり防止地域に指定されている地すべ り地は65力所あるが，てれらの备地すべり地の大部分に ついては高知大学農学部の杤木博上により詳しく調查さ れている2リ。それによると, 高知県下の大部分の地すべ り地は古生層の破砕帯中に存在しており, 徂北部を東北 東加西南西方向に分布する。これらを地質学的に区分 すると, 北から三波川結晶片岩地带地すべり地, 御荷鉾 緑色岩類地带地すべり地ならびに秋父糸帯地すべり地の 三つに大別される。乙れを詳しく検討すると，三波川結 晶片岩地带は北部の三波川带主部之南部の特に破哗作用 のいちじるしい三波川南縁带および三波川带主部之同南 縁带とを分けている清水構造带の三帯に細分される。三 波川結晶片岩地带の地すべり地は，一般に黒色片岩の部 分に多く分布し, 緑色片岩の部分にはほとんど見られな い。三波川带主部, 清水構造線, 三波川南縁帯飞分布す る地すべり地を比較すると, 清水樍造带および三波川南 緑帯の方が三波川主部より地すべり地の分布密度が高 く，その規模む大きい。そして悪性の地すべりが多いた めそれによる被害む大きい。しかし，一般に地すべり地 と非地すべり地との区別が後述する御荷鉾緑色岩類地带 の地すべり地のようにはっきりはしていないょうであ る。

三波川南縁带の南侧に御荷鍮緑色岩類と呼ばれる地質 が分布するが，乙の地質の存在する部分には非常に多く の地すべり地を見ることができる。とくに緑色岩類の中 であ集塊岩質緑色岩および千枚岩質緑色岩, 凝灰岩質緑 色岩の分布する地域に地すべりが多い。御荷鉾緑色岩類 地带の地すべりは三波川絬鼠片岩地帯の地すべりと比較 すると，地すべりの規模が大きく，移動形態む後者は間 欠的に滑動するのに対して, 前者は常時緩慢に滑動する
ものが多い。そのためか御荷鉾緑色岩類地带の地すべり 地は非地すべり地との区別が非常にはっきりしている。 土地利用の面からみると, 三波川結晶片岩地带の地すべ り地には傾斜畑が主であるのに対して, 御荷鉾緑色岩類 地帯の地すべり地では地下水が喆富に存在し，緑色岩類 が風化粘土化されやすいためか，非常に高い標高にまで 水田が開かれているのを見るととができる。てれは，御 荷鉾緑色岩類地带地すべり地の特色とされている。

御荷鉾緑色岩類地带の南側に存在する秋父罢带も破砕 帯地すべりと関係の深いあのがあるが，地すべり地の分 布状態は地域により大きな造いが認められる。秩父累帯 はほぼ東西に走る主要な二つの断層線により, 北帯, 中 帯，南帯の三帯に細分されるが，地すべり地は北帯と中 带を分ける黒瀬川構造带およびその北部に沿って主とし て分布している。岩質的には粘板岩および東西性の断層 に沿って貫入した超塩基性岩である蛇紋岩の分布する地 域に多くの地すべり地が存在している。

てのように，一括して破砕带型地すべり地と呼んでい るものの中にも，地質，岩質の相造によって買なった移 動形態, 規模, 地下水の賦存状態, 土地利用をむつ地す ベり地が多数存在している。そてで, 前述のように買な った地带に分布する地すべり地がその地質，岩質の相 造, 地下水賦存状況の㥵遨等によって, 電気比抵抗値的 にどのような相造として表わされるかを知るために，で きるだけ多くの地すべり地において電気探査を行なって みた。

現在までに電気探相が実施された地すべり地は次の14 カ所である。

三波川結晶片岩地带清水構造带……永㴊

" 南縁 耐……川非, 中内

御荷鉾緑色岩類地带……立㓶, 西川, 宗津, 如谷川, 松木野, 和田 

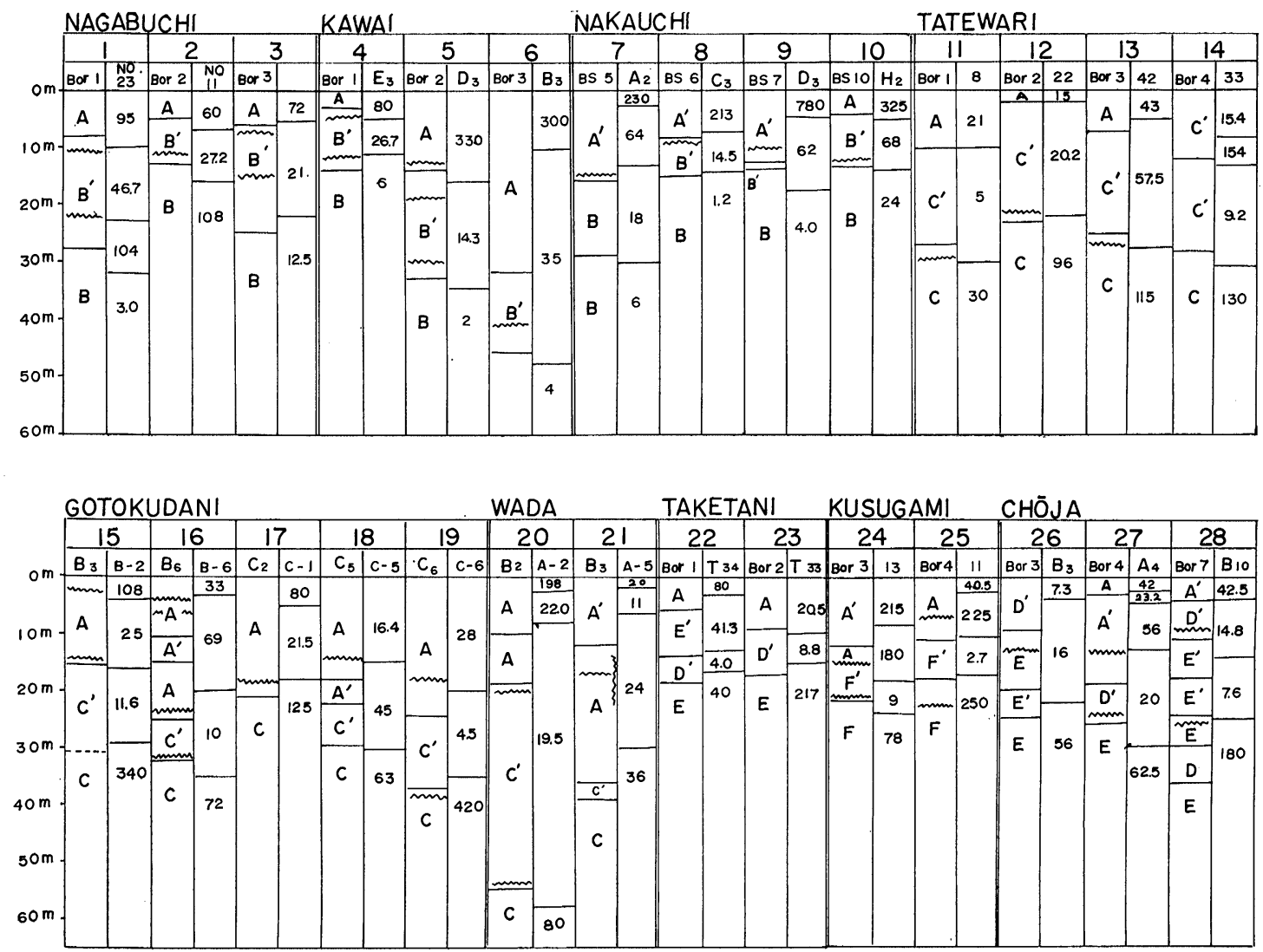
$\mathrm{A}:$ 粘土混り磼または砶混り粘土
$\mathrm{A}^{\prime}$ : 崖錐
$\mathrm{B}:$ 結晶片岩類の末風化のもの
$\mathrm{B}^{\prime}$ : 結晶片岩類の風化粘土化したもの
$\mathrm{E}:$ 粘板岩の未風化のもの $\mathrm{E}^{\prime}$ : 粘板岩の風化粘土化したもの $\mathrm{F}:$ 辉緑凝灭岩の未風化のもの $\mathrm{F}^{\prime}$ : 輝緑疑灭岩の風化粘土化したもの

mW SLIDE SURFACE BY

INTERNAL STRAIN METER

図-2 電気探查による地下構造推定図と試錐柱状図との対比

秩父累 带……野老山

秩父黑瀬川構造带.......竹谷, 長者, 楠神, 円行寺

\section{3. 電気探查による地下構造推定について}

各地すべり地に打ける地下棈造を推定するために，電 気探査により得られた測定値を $\rho_{a} \sim a$ 曲線に表わし，標
準曲線を用いて解析し，その解析結果を各地すべり地の 断面図に記入，地下構造を推定した。

上記の方法により推定された各地すべり地の地下構造 断面図と, その推定結果に基づいて夷施された試錐調查 結果とを対比したものが図-2である。罒中波形状の線で 示してあるのは試錐孔を利用して埋設された地中内部ひ

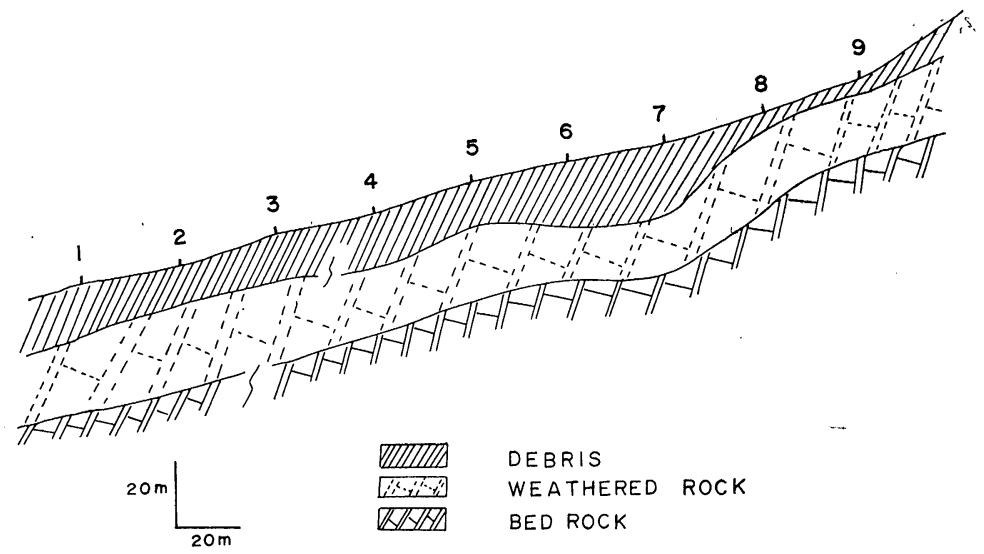

図-3 如谷川地すべり地地下構造推定図 


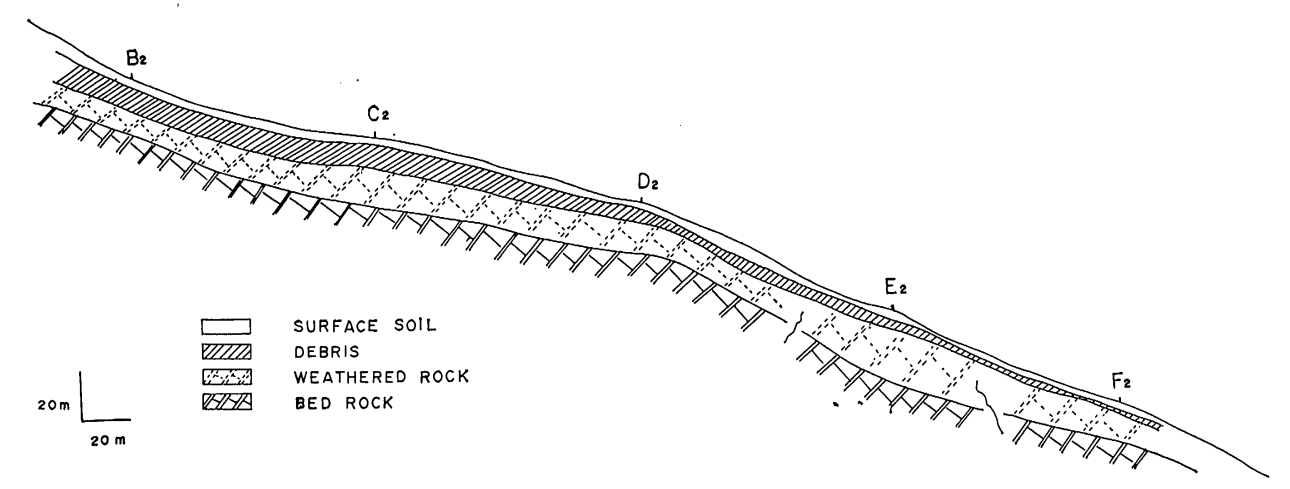

図-4川井地すべり地地下構造推定図
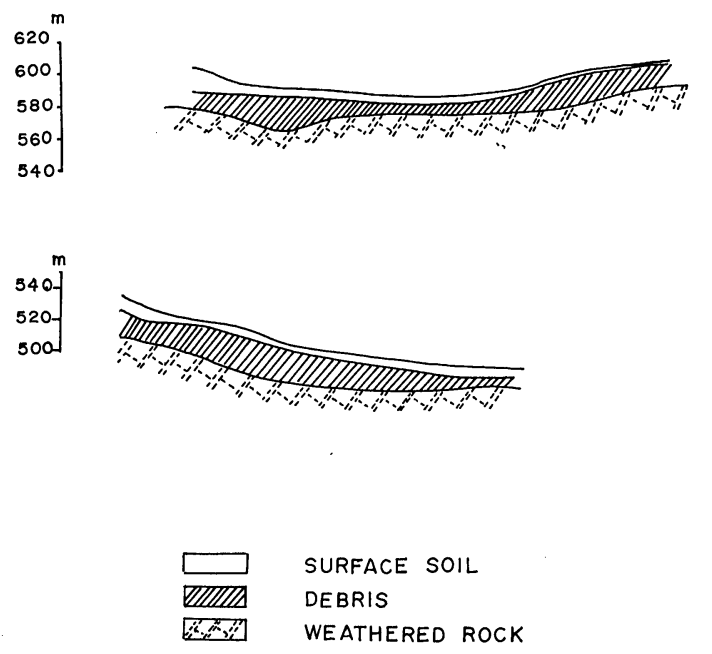

図-5 西川地すべり地地下構造推定図

ずみ計の観測結果から得られた地すべり面深度である。 なお，電気探查ですべり層となる可能性が強いと推定 した層の中には，いくつものすべり面が存在していると とが地中内部ひずみ計の観測により示されている。との ことは破砕帯型地すべり地においても第三紀層型地すべ り地で適応されたすべり層という概念が適応できる可能 性の存在しているととを示しているものと考えたい。

図-2を吟味すると次のようなととが示されている。た とえば如谷地すべり地のように土石流跡が現在さかんに 地すべり滑動を起している場合には，電気探査による基 岩推定深度と試錐調查による風化基岩深度とが非常によ
く一致するとと屯に，すべり層またはすべり面の推定深 度む地中内部ひずみ計の钼测により得られたすべり層ま たはすべり面深度とよく一致している（図-3）。また， 川井, 中内, 立割, 和田, 長者, 楠神などの各地すべり 地のように崖錐あるいは砂混り粘土と比較的浅い30〜 40 $\mathrm{m}$ に深度に存在する基岩層之の境界またはその付近が地 すべり活動を起こしている地すべり地の場合も雪気探査 の推定結果と試錐調查結果および地中内部ひずみ計钼测 結果とがよく一致しているようである(図-4)。しかし， 西川, 永㴊地すべり地のように崩積土およびその下の基 岩風化層が非常に厚く, 基岩までの深度が $70 \sim 80 \mathrm{~m}$ と 深い場合には，電気探査により基岩深度を推定すること はむずかしい（図-5)。しかし，地中内部ひずみ計等の 観测結果を総合して考察すると，乙のような地すべり地 の場合は基岩と基岩風化層との境界およびその付近のす べり面よりむむっと浅い所に存在するすべり面の方が現 実に田畑人家に被害を及ぼす影響が大きいととが示され ているととから考えて, 浅いすべり面に重点を置いて調 查することが必要であるととが暗示されている。つま り, 現実に田畑家屋に被害を与えるようなすべり面また はすべり層は風化基岩層内, またはその上の崩積土層内 にすべり面をあっており，一つの大きな地すべり地形は していてあ現実にはその中にいくつあのブロックに分離 して比較的浅いすべり面またはすべり層をむって地すべ り活動を起てしているととが推定されたのである。ての ような地すべり地で電気探査を行なう場合には, 深い基 岩深度を検出するのはむずかしいので, 現実に田畑家屋

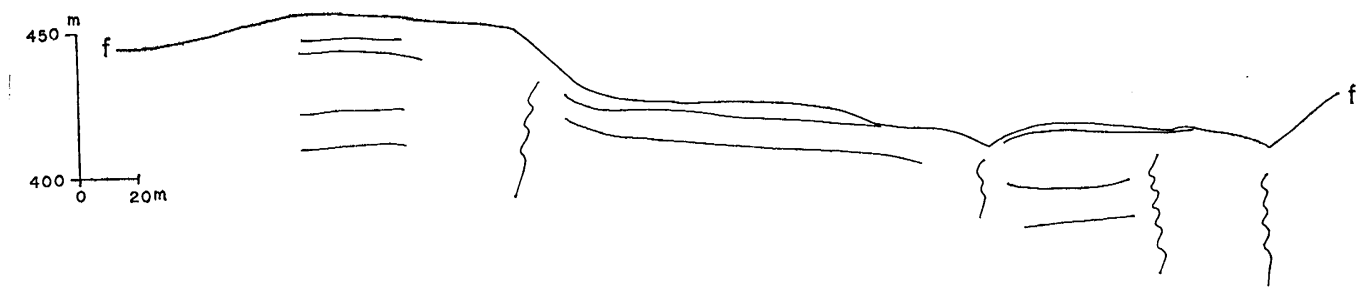

図-6 松木野地すべり地地下構造推定図(1) 
に被害を及ぼしているすべり面またはすべり層の検出に 焦点をしぼれば電気探查も充分通用することが示され た。

つぎに, 各地すべり地の電気探査による地下構造推定 図を描いてみると，所々に電気比抵抗值的に地下構造の 不連続な所が存在しているのに出会う(図-6)。てれら の不連続な個所は, 各測線每ではなにを意味するのか不 明確であるが, 調查した地すべり地の地形図上に不連続 な個所を記入してゆくと，その地すべり地をいくつかの ブロックに分離できるような線を描くことができる。こ のように，いくつが分離された各ブロックがその地す ベり地においてどういう意味をむっているかは，それぞ れの地すべり地によって異なる。たとえば, 松木野地す ベり地の場合には地すべり地域が四つのブロックに分け られて，それぞれ異なった意味をむっており，一つ一つ が活動形態が異なっているととが推定されている。との ととは4.において詳しく述べるととにする。

\section{4. 電気探査同深法による解析結果について}

電気探查結果の表現法に同深法という表現方法があ る。乙れは各測点で得られた測定值の中で電極間隔 $a$ を 一定にしたとき（たとえば， $a=2 ， 5 ， 10 ， 16 ， 20 ， 26$, $30,38,42,50 \mathrm{~m})$ の見掛け比抵抗值を测点をプロット した地すべり平面図上に記入して，等見掛け比抵抗值分 布図を描いたとき，それがほぼその電極間隔に等しい深 度の見掛け比抵抗值の分布状沉を表わしていると考える あのである。電極間隔 $a$ を種々に変化させた場合, その 電極間隔敒等しい哚度における見掛け比抵抗值の分布状 況がどのように変化するかを検討するむのである。

上記の作業を各地すべり地において行ない，各電極間 隔每海等見掛け比抵抗値分布図を描く之，一つの地すべ り地に, 一つあるいはそれ以上の低見掛け比抵抗值分布 地域と, 高見掛け比抵抗值分布地域とが存在しているの が見られる。第三紀層型地すべり地では，てのうち低見 掛㚈比抵抗值分布地域は地下水の啙富に存在する地域, 地すべり土塊の風化粘土化の進んだ地域あるいは将来地 すべり活動のはげしくなる可能性の存在する地域のいず れかを意味するというととが確認されている3!。そてで, 破砕帯型地すべり地にも一応とれらのととが適応できる あの之仮定して, 各地すべり地で同深法による解析を行 なってみた。その結果, 立割・和田・長者の各地すべり 地に存在する低見掛け比抵抗値分布地域は地下水の豊富 な地域であることが排水用横孔試錐および集水井を施工 した結果から実証された。一方, 如谷川・野老山・松木 野・長者などの地すべり地に存在する低見掛け比抵抗值 分布地域は地すべり活動のはげしい地域を意味している ことが地表面移動量観測結果および地中内部ひずみ計観 測結果から実証された。その他の破砕帯型地すべり地に
おいてあ低見掛け比抵抗值分布地域は存在しており, 地 質・地形・試錐等の各調查および他の地すべり諸調查結 果を考慮してその地域のもつ意味を検討した結果，地下 水の豊富に存在する地域, 旧地すべり活動跡, 地すべり 土塊の風化粘土化の進んだ地域，現在地すべり活動のは げしい地域等の意味をむっているととが推定されてい る。

つぎに各電極間隔において得られた低見掛け比抵抗値 分布地域を 1 枚の図にまとめると, 低見掛け比抵抗値分 布地域がいくつかのある限られた地域に存在しているこ とがわかる。そこで, この図と3.で述べた地下構造の不 連続な個所を記入した図とを対比するととにより，一つ の地すべり地をいくつかのブロックに分離することがで きるか否かを検討するととができるとともに，いくつか に分離するととができた埸合, 地形地質調查結果および 試錐調査結果, 地中内部ひずみ計锥測結果等を考虑する ことにより各ブロックがその地すべり地においていかな る意味をむっているのかを充分検討するてとができるこ とがわかった。

例として松木野地すべり地を例にあげて説明してみよ う(図-7)。乙の地すべり地は御荷鉾緑色岩類地带に存 在し, 地すべり土塊は主として集塊岩および千枚岩質緑 色岩の碩扔よび粘土化したもので構成されている。地形 的には, 標高 $570 \mathrm{~m}$ 代の山に周囲をかてまれており, 地 すべり上部は標高 $520 \mathrm{~m}$ くらい, 岾まで真近の所にあ る。一方, 地すべり末端部は標高 $310 \mathrm{~m}$ 付近にあり, こ の間にいくつかのブロックに分かれて地すべり土塊が活 動しているように見うけられた。地すべり地両側は急傾 斜によって切られており, 地すべり地形が非常にはっき りとして扰り, 御荷鉾緑色岩類地带の地すべり地の特色 がよく表われている。土地利用は山頂 $(574 \mathrm{~m})$ の側近 まで水田が開かれており, 地すべり地のでく一部を除い てはすべて水田に利用されている。

当地すべり地で電気探查を行ない, 地下構造を推定し たところ，図-7に見られるように各測線断面図にいくつ かの不連続な所が存在している。そてで，3.で述べたよ うに，乙れら不連続な個所を地形平面図に記入してみた とてろ, 当地すべりは, A, B, Cの3ゾロックに分漓 できるととがわかった（図-8）。乙れら各ブロックが当 地すべり地に㧊いて有する意味を探るために電極間隔 $a$ $=2,5,10,16,20,24,30,36,42,50 \mathrm{~m}$ に打ける 等見掛け比抵抗值分布図を作製し，乙れより低見掛け比

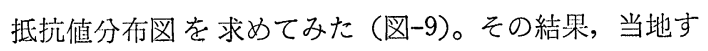
べり地には五つの低見掛け比抵抗值分布地域が存在して おり，それぞれ電極間隔の大きいとてろ，つまり地すべ り樑部ではつながりをもっているととがわかった。

ことで, 図-8と図-9とを対比させてみると，Aブロッ ク $=1$ ブロック， $\mathrm{B}$ ブロック $=2,3$ ブロック, $\mathrm{C}$ ブロッ 

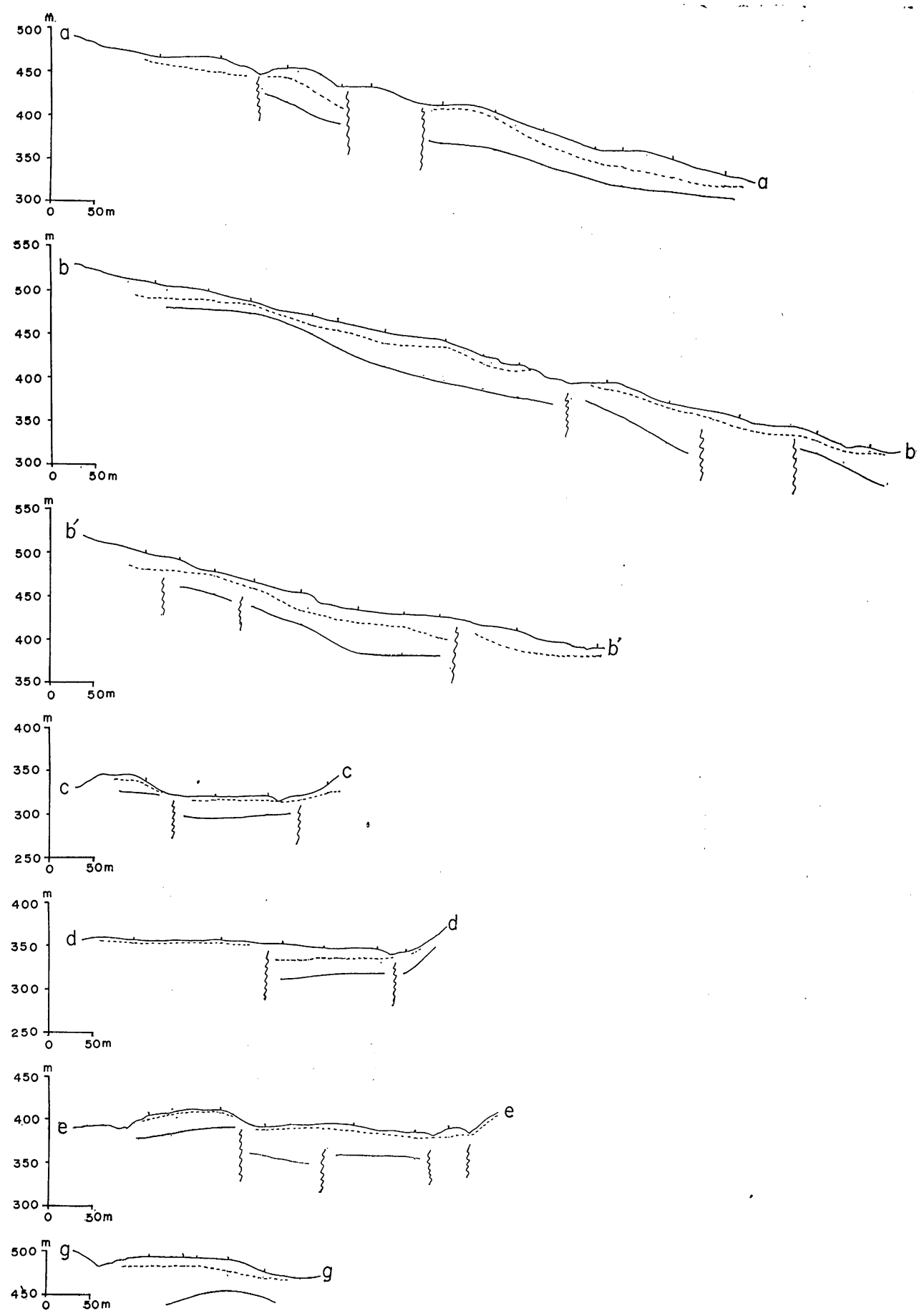

図-7 松木野地すべり地地下構造推定図(2)

ク $=4,5$ ブロックに対比されるととがわかる。

つぎに，各低見掛け比抵抗值分布地域のむつ意味を考

えてみよう。一般に，地すべり地における低見掛け比抵 抗值分布地域は地下水の豊富な所, 地すべり土塊の風化 粘土化の進んでいる所，将来地すべり活動を起す可能性 のある所あるいは現在さかんに地すべり活動を起としつ
つある所のいずれかに属するととが確認されている。当 地すべり地のそれが，乙れらのうちいずれに属するかは 一概に決められないが, 地質, 地形, 地下水状態をふま えて判断すると次のようになろう。1ブロックは御荷鉾 緑色岩類地带地すべり地の特色の一つである高標高まで 豊富な地下水が存在しているという事実を考えると，乙 


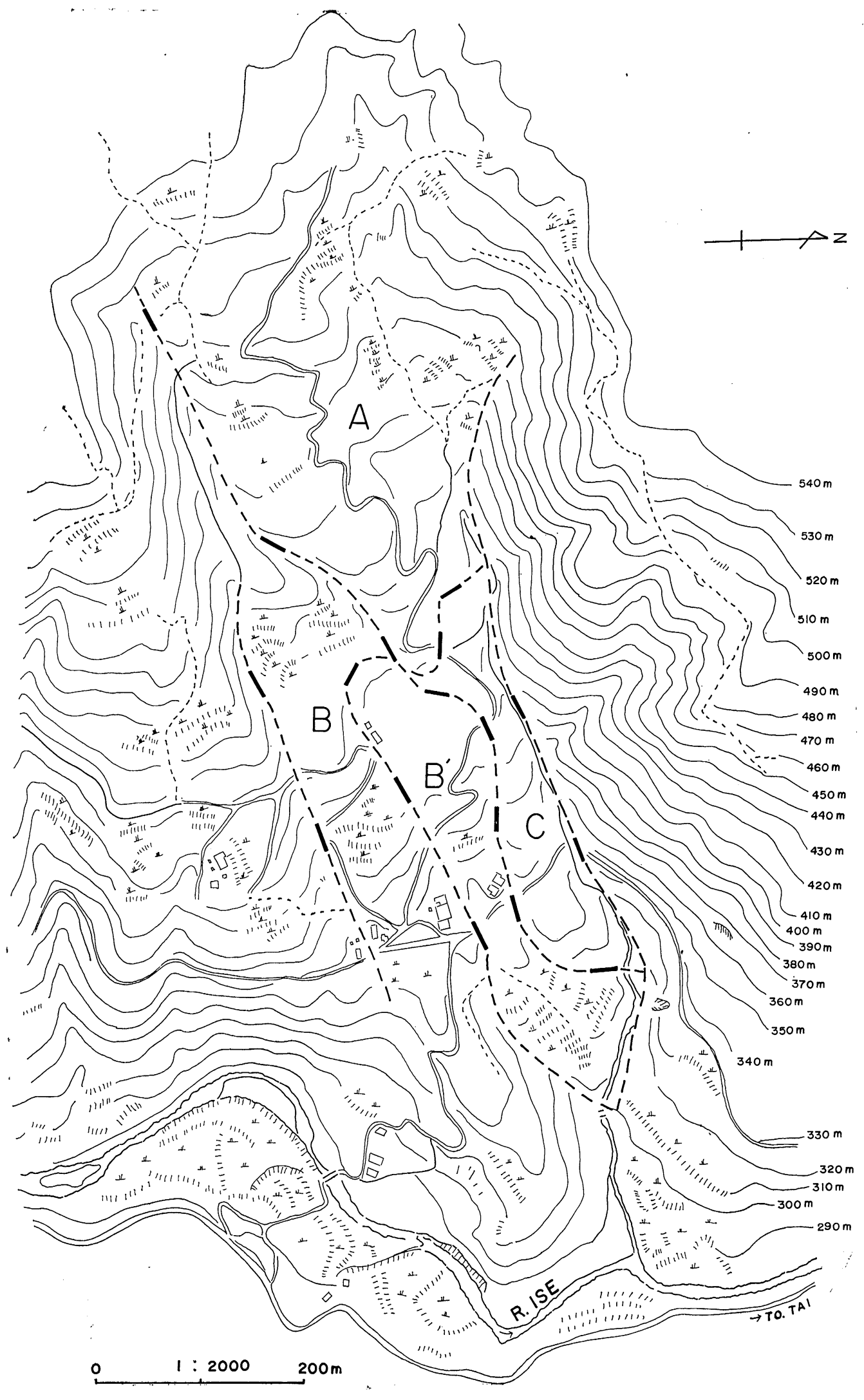

図-8 松木野地すべり地（図-7より得られたブロック図） 


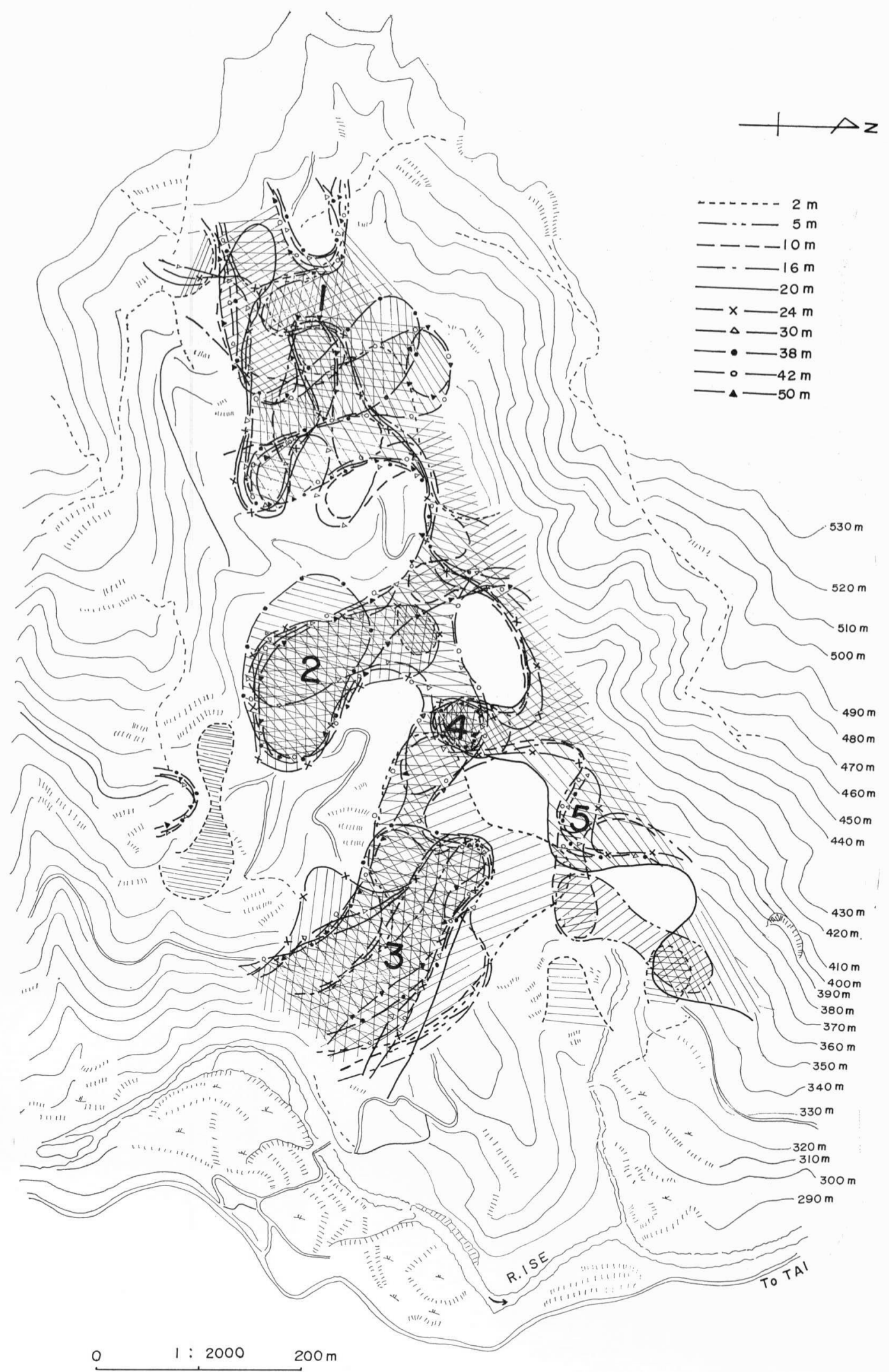

図-9 松木野地すべり地一低見掛け比抵抗値分布図 $\left(\rho_{a} \leqq 20 \mathrm{k} \Omega-\mathrm{cm}\right)$ 
の付近に地下水を供給させるなにかが存在していて，そ こから多量の地下水が地すべり土塊内に供給されている ために低見掛け比抵抗值を示すようになったすのと推定 される。そして，1ブロックの北寄りの土塊は地下水供 給の特に多いために土塊の粘土化が促進されて流動すべ りを起としていることが推定される。この地下水はブロ ック $\mathrm{A}$ の北侧の谷沿いに流下している土石流跡のブロッ クCに流入しているてとが予想される。一方, 地すべり 地を斜めに横断している谷 (?) より供給される地下水 のためにブロック $\mathrm{B}^{\prime}$ を取り罒むような形でブロック 2 が存在している。とのブロックからブロック $\mathrm{B}^{\prime}$ へ供給 される地下水がブロック $\mathrm{B}^{\prime}$ の活動の一端を担っている あのと推定される。ブロック $\mathrm{B}^{\prime}$ の上部には横断谷とブ ロック 2 より供給される地下水のために梁部まで低見掛 け比抵抗值を示すブロック 4 が形成されている。ブロッ ク 3 はブロック $\mathrm{B}^{\prime}$ より南東に向かって存在しているが, このブロックは現在地すべり活動を起てしていない土塊 であることを考えると, 将来ブロック $\mathrm{B}^{\prime}$ から供給され る地下水によりさらに土塊の風化粘土化が進んだ場合に は，地すべりを起てす可能性む考えられるブロックであ る。ブロック 5 はブロック 1 より地すべり地北寄りの谷 に沿って流下してきた地下水により地質的条件も伴っ て, 特に深部まで風化粘土化が促進されている可能性が ある。

当地すべり地には, 地すべり上部に存在する地下水が 下方へ流下したととにより生じた低見掛け比抵抗值分布 地域と, 地すべり中央の横断谷より供給される地下水に より生じた低見掛け比抵抗值分布地域との 2 種類のあの が考えられる。そして，ブロック $1 ， 4 ， 5$ は風化粘土化 の促進されつつある地域, ブロック 2 は地下水の比較的 豊富に存在する地域, ブロック 3 は除々に土塊が風化粘 土化されて将来地すべり活動を起てす可能性のある地域 であることが推定された。

\section{5. 地質構造帯別にみた比抵抗値の 相異につい $\tau$}

各地すべり地における地下構造推定図の表層, すべり 層, 基岩の各比抵抗值が各地質構造帯によって種々の相 違を示すか否かを検討する目的で表-1を作製した。との 表中に示されている各地すべり地の各層每の比抵抗值 は，地すべり地内で一つの連続した層とみなせる地層中 に含まれる比抵抗值を算術平均して得られたあのであ る。乙のような方法で求めた比抵抗値を一つの層の代表 値と見なしてよいものか否かは検傠する必要があると思 うが，今回はこの方法である層の代表值を決めるととに より, 各地質構造帯間に比抵抗の差が認められるか否か を検討してみた。表中には各地すべり地の平均的地下構 造図の横に，その地すべり地の平均的試錐柱状図を対比
させて扔いた。

との表を通覧すると同じ地質構造带に属する地ず゙り 地同志では各層每の比抵抗値に相当似加寄った值が得ら れているが，それぞれ巽なった地質構造帯に属する地す べり地の間にはかなりはっきりとした比抵抗值の相迲が 存在しているととがわかった。つぎに, 各地質構造帯毎 にその様子を記してみる。

三波川結晶片岩地帯清水棈造帯に属する地すべり地： 表層は比抵抗值 $105 \mathrm{k} \Omega-\mathrm{cm}$ を示し, 主として崖錐より なっている。すべり層は $171 \mathrm{k} \Omega-\mathrm{cm}$ の比抵抗值を示し， 主として結晶片岩類の風化粘土よりなっている。基岩と 推定される層は比抵抗値 $18 \mathrm{k} \Omega-\mathrm{cm}$ を示し, 結晶片岩類 の未風化のものよりなっている。

三波川結晶片岩地带南縁帯に属する地すべり地：表層 は 115. 5 166. $3 \mathrm{k} \Omega-\mathrm{cm}$ の比抵抗值を示し, 崖錐（粘土 混り礫)よりなっている。上部すべり層は比抵抗值 165.6 $\sim 285.5 \mathrm{k} \Omega-\mathrm{cm}$ を示し, 結晶片岩類の硆混り粘土となっ ている。下部すべり層は比抵抗值 $35.7 \sim 71.1 \mathrm{k} \Omega-\mathrm{cm}$ を 示し, 結晶片岩類の破砕されたものよりなっている。基 岩と推定される層は比抵抗值 $4.9 \sim 7.7 \mathrm{k} \Omega-\mathrm{cm}$ の低比抵 抗値を示しており, 結晶片岩類の硬質未風化のあのより なっている。

御荷鈝緑色岩類地带に属する地すべり地：表層は55.6 $\sim 73.5 \mathrm{k} \Omega-\mathrm{cm}$ の比抵抗值を示し, 緑色岩類の崖錐より なっている。すべり層は比抵抗値 $13.3 \sim 28.6 \mathrm{k} \Omega-\mathrm{cm}$ を 示し, 主として緑色岩類の風化粘土化したものよりなっ ている。基岩と推定される層は $74.3 \sim 163.4 \mathrm{k} \Omega-\mathrm{cm}$ の 比抵抗值を示し, 緑色岩類の硬質未風化のものよりなっ ている。なお，地質図上で御荷鉾緑色岩類地带の南端に 属している宗津地すべり地は深部において秩父糸帯に属 する地層が存在しているために, 比抵抗值は御荷鉾緑色 岩類地带のものとは異なっており, むしろ秩父照帯に属 させる方がよいと思われる值を示している。また, 如谷 川地すべり地は土石流跡が地すべりを起こしているため に表層の比抵抗値がいちじるしく高くなっている。

秩父糸帯北帯に属する地すべり地：表蕒は比抵抗値 $98.7 \mathrm{k} \Omega-\mathrm{cm}$ を示し, 蛇紋岩および粘板岩の碩を含んだ 粘土層となっている。すべり層は $16.4 \mathrm{k} \Omega-\mathrm{cm}$ の比抵抗 值を示しており, 粘板岩の風化粘土化されたむのよりな っている。基岩と推定される層は比抵抗値 $371.7 \mathrm{k} \Omega-\mathrm{cm}$ を示し, 粘板岩の未風化のあのよりなっている。

秩父累帯黒瀬川構造帯に属する地すべり地 : 表層は 67. $6 \sim 281.6 \mathrm{k} \Omega-\mathrm{cm}$ の比抵抗值を示し, 蛇紋岩および粘 板岩の碩を含んだ粘土層之なっている。すべり層は 16.0 $\sim 27.4 \mathrm{k} \Omega-\mathrm{cm}$ を示し, 蛇紋岩および粘板岩の風化粘土 化されたすのよりなっている。円行寺地すべり地のみ基 岩層とすべり層の間に $7.2 \mathrm{k} \Omega-\mathrm{cm}$ の比抵抗値を示す層 が介在しているが，比抵抗值书よび試錐資料よりみて, 


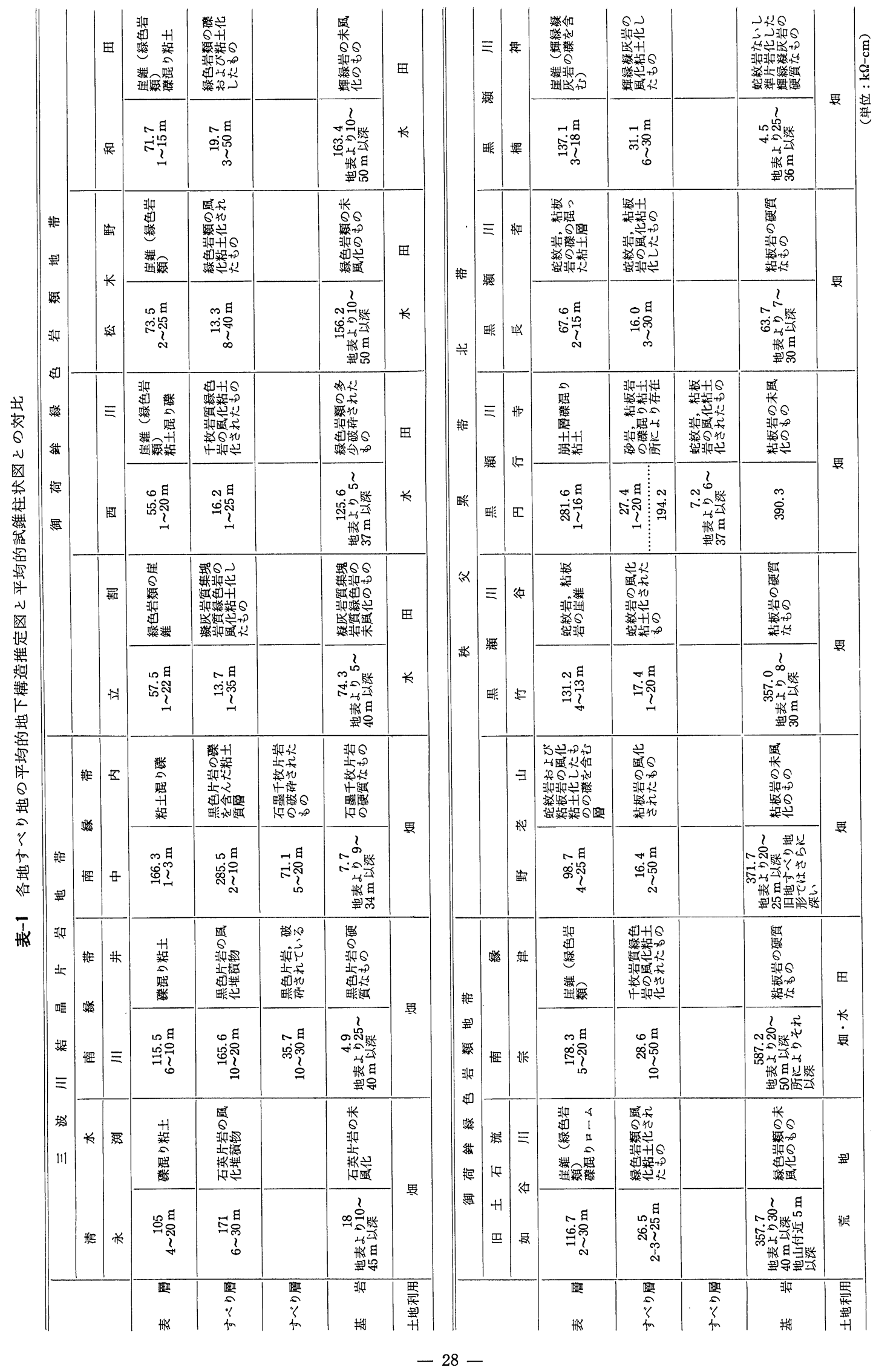


表-2 比抵抗值より見た破㸴帯型地すべり地

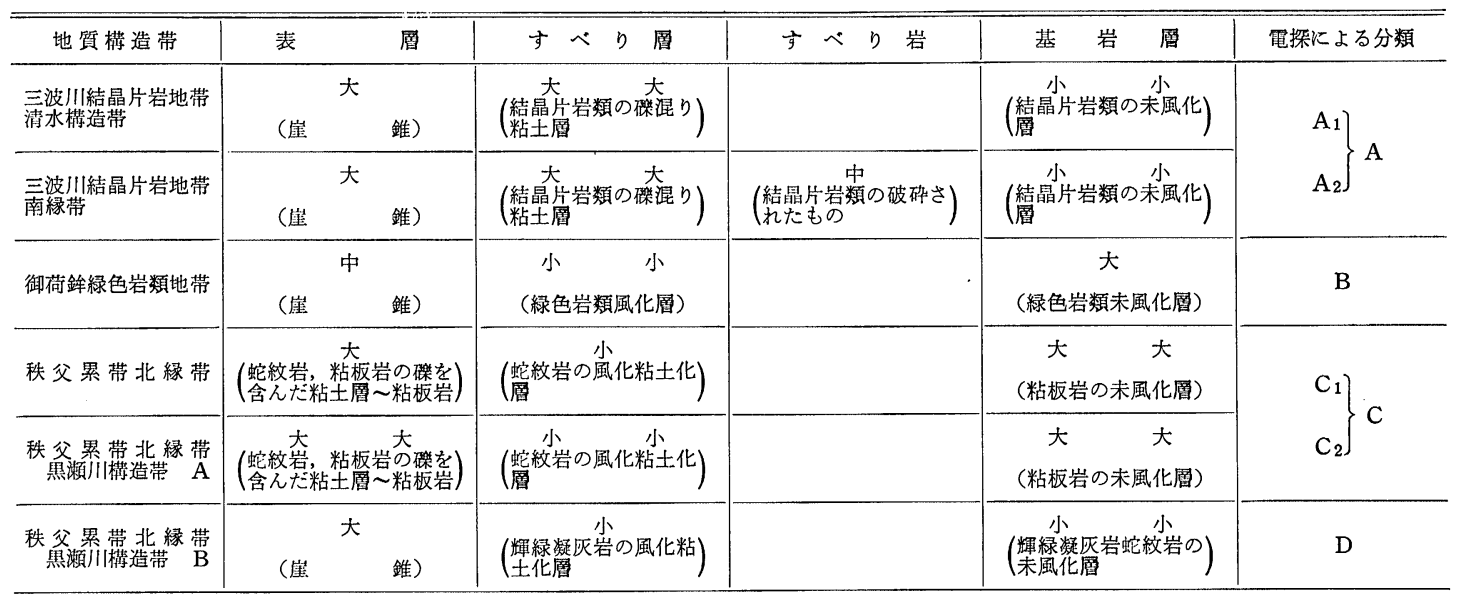

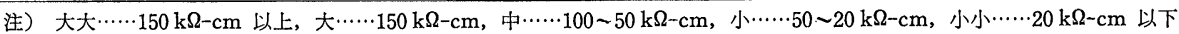

ての層はすべり層に編入してさしつかえないと思われ る。基岩と推定される層は比抵抗値 $357.0 \sim 390.3 \mathrm{k} \Omega$ $\mathrm{cm}$ を示し，粘板岩の未風化のものよりなっている。た だし，長者地すべり地の基岩層と推定されるすのは多少 粘板岩が破砕されているために，63.7 k $2-\mathrm{cm}$ と少し低 い比抵抗值を示している。同じ黒瀬川構造带に属する地 すべり地の中でも楠神地すべり地だけは地質構造が他の 地すべり地と異なっているために比抵抗值においてもそ れが認められている。つまり，表層は $137.1 \mathrm{k} \Omega-\mathrm{cm}$ の 比抵抗值を示し，崖錐よりなっている。すべり層は31.1 $\mathrm{k} \Omega$-cm の比抵抗值を示し, 輝緑凝灰岩の風化粘土化し たものよりなっている。基岩と推定されるものが，比抵 抗值 $4.5 \mathrm{k} \Omega-\mathrm{cm}$ と黒瀬川棈造带に属する地すべり地と しては非常に低い值を示しており，蛇紋岩ないし準片岩 化した輝緑凝扊岩の硬質未風化のものよりなっている。

以上, 各地質構造带に属する地すべり地の各層の比抵 抗値とその岩質について述べてきたが，乙てで各地質構 造帯每にまとめて表にあらわすと表-2のごとくなる。

筆者は電気比抵抗値より見て破砕带型地すべり地を表 -2の右欄に示すように四つのグループに分けてみた。

$\mathrm{A}$ 型：三波川結晶片岩地帯に属する地すべり地が含ま れるあので比抵抗值の面から見ると表層一すべり層一基 岩層はそれぞれ大一大大一(中)一小小という形をとって おり，地質的には崖錐一結晶片岩類の風化層一(結晶片 岩類の破砕されたもの)一結晶片岩の未風化層となって いる。 $\mathrm{A}$ 型はさらに $\mathrm{A}_{1}$ と $\mathrm{A}_{2}$ 型に細分するととができ る。

$\mathrm{B}$ 型：御荷鉾緑色岩類地带に属する地すべり地がこれ に含まれる。比抵抗值の面から見ると表層一すべり層一 基岩層はそれぞれ中一小小一大という形をとるもので， 地質的には緑色岩類の崖錐一緑色岩類の風化層一緑色岩 類の未風化層となっている。

C型：秩父累带北帯および黒瀬川構造帯に属する地す
ベり地の大部分がこれに含まれる。比抵抗值の面から見 ると表層一すべり層一基岩層はそれぞれ大（大大）一小 (小小)一大大の形をとるあので, 地質的には蛇紋岩, 粘 板岩の礫を含んだ粘土層一粘板岩, 蛇絞岩の風化粘土化 層一粘板岩の未風化層となるあのである。C型は $\mathrm{C}_{1}$ と $\mathrm{C}_{2}$ 型に細分される。

$\mathrm{D}$ 型 : 秋父累带黒瀬川棈造带に属する地すべり地ので く一部のあのがてれに含まれる。比抵抗值の面から見る と表層一すべり層一基岩層はそれぞれ大一小一小小の形 をとるむので，地質的には崖錐一輝緑凝灰岩の風化粘土 化層一蛇紋岩, 輝緑凝灰岩の未風化層となるあのであ る。

表-2に示されているように，同じ破砕带型地すべり地 といわれているものでも基岩とされている層の比抵抗值 はその基岩により非常に異なった值を示していることが わかる。たとえば，A型の結昆片岩類では比抵抗值 20 $\mathrm{k} \Omega$-cm 以下となっており， B 型の緑色岩類では $130 \mathrm{k} \Omega$ $-\mathrm{cm}$ 程度の比抵抗值を示す。また，C型の粘板岩では $240 \sim 440 \mathrm{k} \Omega-\mathrm{cm}$ という高い值を示すのに対して，D型 の輝緑凝灰岩では $4.5 \mathrm{k} \Omega-\mathrm{cm}$.という低い比抵抗值を示 している。さらに，各型において基岩層が風化粘土化さ れた場合の比抵抗值の変化の仕方にも二とおりあるとと が示されている。一つは A，D型に見られるように基岩 層が風化粘土化されると比抵抗值が上昇する場合であ り，他の一つは B，C型に見られるように基岩層が風化 粘土化されると比抵抗值が急激に低下する場合である。

以上のように同じ破砕带型地すべり地であ岩質により いちじるしい比抵抗值の差があるととあに，基岩が風化 粘土化した場合にも二とおりの比抵抗值の変化の仕方が あることがわかった。これらの諸事実は岩質のいかなる 性質により生じるものか, 岩質の相造と地下水との関係 のみでは説明しきれない点があるので今後解明してゆか なくてはならない問題である。 


\section{6. まと め}

破砕滞型地すべり地において電気探查を実施し，その 有意性の有然を検討した結果, 同型地すべり地において む電気探查は種々の有益な情報を提供してくれるととが わかった。

地下㯕造推定図よりつぎの情報が得られる。

1. 地すべり地の地下㭋造の大要を知るととができ る。

2. 基岩層, すべり面の深度およびその形状に関して かなり正確な情報を得ることができる。

3. 電気探查による推定璂岩深度之試錐調查による基 岩深度との誤差は次の順で大きくなる。崩堆土が比 较的薄い地すべり（土石流跡がすべっているような 型（すべり面 $10 \sim 20 \mathrm{~m})$ )一崩堆と風化基岩とがす べっているような型（すべり面 $30 \sim 40 \mathrm{~m}$ )一崩積土 と哚い風化基岩とがすべっているような型（すべり 面 $20 \sim 80 \mathrm{~m}$ )

4. 地下構造断面図に見られる比抵抗值の不連続な所 はその地すべり地の地形図にその個所を記入するて とにより，その地すべり地をいくつかの意味のある ブロックに分離するととができる。

5. 基岩屬の深度が非常に深く電気探查でその深度を 推定できない場合でむ，地表面に被害を与えている 浅いすべり層は充分榆出することができる。

同深法による解析によってつぎの情報が得られる。

1. 低見掛け比抵抗值分布地域は地下水の豊富な地 域, 現在地すべり活動のはげしい地域，地すべり土 塊の風化粘土化の促進されている地域あるいは将来 地すべり活動を起こす可能性の存在する地域である ことが推定された。ある低見掛け比抵抗值が上記の いずれの地域に属するかは，その地すべり地の地 形, 地質およびその他の諸調查, 諸現象を考虑して 判定する必要がある。

2. 低見掛け比抵抗值分布地域抢よび地下構造推定図 で得られた比抵抗值の不連続な個所を組み合せるこ とにより，地すべり地をいくつかのブロックに分離 することができ，その地すべり地の地形，地質抒よ び試錐調查結果, 地中内部ひずみ計観測結果を考慮 することによって, 各ブロックのその地すべり地に おいて有する意味およびその移動機構を推定するこ とができる。

一方, 比抵抗值より破磪帯型地すべり地を検討すると 次の事柄が推定できる。

1. 比抵抗値よりみた破砕带型地すべり地にはその地 下構造において四つの型が存在する（表-2）。

2. 地すべり地の基岩層と推定される層の比抵抗值は その岩質によりいちじるしい相異が存在する。

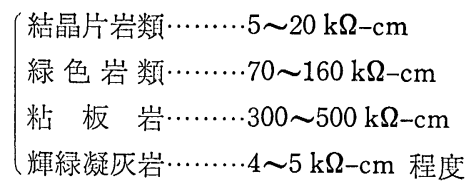

3. 基岩が風化粘上化する場合にその比抵抗值の変化 の仕方に二とおりの方法が存在する。

(a) A，D型のように比抵抗値が急激に増加す る場合 (約10倍程度)

(b) B，C型のように比抵抗值が急激に減少す る埸合（約10〜20分の 1)

今後は電気探查から見た破砕带型地すべり地にいろい ろの相䢰点が存在するととがわかったので，乙れらの相 違点がどのような因子によって生じたのかを微地形掞よ び地質調查, その他, 種々の地すべり調查の結果を分析 して考案していきたいと考えている。とくに基岩層の比 抵抗值のいちじるしい相䄐の存在する原因书よび基岩が 風化粘土化した場合の比抵抗値の変化の仕方の垶いが， 何により生ずるのかを各型の地すべり地の岩を採取し, 種々の室内実験を行なって灮明していきたい。

\section{7. 謝辞}

本小論を酱くに当り終始適切な御助言をしてくださっ た山口真一教授, 高田雄次助教授ならびに資料收集に際 し種々の御便宜を計ってくださるととむに調查に関して 適切な御助言をしてくださった高知大学農学部杤木省二 教授に心からの謝意を表します。

現地調査に当りましては，高知県土水部砂防課拈よび 県下土木出張所の方々の手定煩わすとともに地元の方々 に大変お世話になったととをこてに記し謝意を表しま す。

現地での資料收集に当っては高知大学農学部および同 大学院の学生諸君の多大な協力を受けました。こてに記 し謝意を表します。

\section{参 考 文 献}

1）竹内篤雄：破砕帯型地すべり地における電気探査の 有意性について，京大防災研年報13号 A，1970．3. pp. $478 \sim 498$.

2）栃木省二：高知県下に㧍ける破砕带地すべりについ て，災害科学シンポジューム講演要旨，1969.

3) TAKAdA, Yūji: A Geophysical Study of Landslides (Application of the Electrical Resistivity Survey to Landslides), Bulletin of D. P. R. I. Kyoto University, volume 18, 1968, Dec. 